\title{
Against The State Ideology on Islamic Online Media in Indonesia
}

\author{
Moch. Syarif Hidayatullah \\ Translation Department \\ Syarif Hidayatullah State Islamic University Jakarta, Indonesia \\ moch.syarif@uinjkt.ac.id
}

\begin{abstract}
This study focuses on the use of the internet of Islamic online media in Indonesia to offer ideology against the state ideology. It was represented by voa-islam.com and panjimas.com, the most intensive sites on offering ideology against the state ideology of the state and also the popular sites with the anti-Pancasila keyword. This study aims to examine the ideological identity of the sites. Discourse Analysis and Content Analysis will be used to dismantle the contents of websites about the state ideology. To find the ideology of the news or articles writers, it is used topic headings and content of news or articles. Based on the analysis of editorial and news or articles, it is known that the sites affiliated with the Salafi groups who want to change the state ideology. They argue that Pancasila is not worthy to be the state ideology. It is also found that the ideology of sites only duplicates the issues from the transnational Islamic movement as a patron of ideology.
\end{abstract}

Keywords - Islamic online media, the state ideology, antiPancasila

\section{INTRODUCTION}

Indonesia as the most populous Muslim country in the world becomes a promising market in the use of the internet. Moreover, at the same time, Indonesians have just enjoyed the freedom of opinion, expression, and information after the fall of the New Order and the rise of Reform Era [1]. No wonder if nowadays internet becomes a new tool of expression for individuals or groups in showing their existence. In fact, in some cases, the cyberspace determines and triggers a person's or a group's success in the real world [2, p. 141].

According to Hootsuite's report, until January 2017 Indonesia is far away from other Southeast Asian (ASEAN) countries. In the report, it is mentioned that internet users in Indonesia are more than 132,7 million and social media users are 106 million. Thailand, the closest competitor, only has more than 46 million internet and social media users.

The facts are among the factors that seem to drive Islamic groups activists in Indonesia both moderate, radical and liberal groups, to take part in making use of the internet for the activities of propaganda issues that become the brand of each group. Various ideologies are offered, although the methods used often tend to be the same, by coercion and being unfriendly to groups who opposed their ideology [2, p. 147]. In the Indonesian context, radical groups are the most active in spreading their understanding and ideology through the Internet. The use of the Internet by radical groups is actually a continuation of their previous activities which were quite intensive in spreading their ideology through books, tapes, videos, television broadcasts, pamphlets, and brochures.

In last years, one of the important issues in radical Islam groups is the state ideology. They are often questioned about Pancasila (the official philosophical foundation of the Indonesian state) as the state ideology. At such cyber media, it is mentioned that Pancasila is not worthy to be the state ideology. They argue that implementation of shariah (Islamic law) or Khilafah is a solution. Until now, there are no researchers studied about the case. The previous researchers only studied about the relation of Islam and the state, such as Azra [3], Fealy and White [4], Assyaukanie [5], Kersten [6]. The new phenomenon of Islamic radical groups resistance to the state ideology in cyberspace is not much discussed by previous researchers.

\section{METHOD}

In this study, I use the same method with which one I use in my article about sectarianism ideology on Islamic online media in Indonesia [2]. This research utilizes content-oriented approach in exposing the discourse discussed in the article or news. This paper uses headlines and editorial articles as a guide to see the topics developed by the site administrator to manage the issue in order to understand his radical ideology. To identify the ideology of the sites administrators on topics of headlines published, "it can be seen from the 'things' that are used by speakers when trying to improve the knowledge of the interlocutor, ask for information, ask the other person to do so in a row" [7]. Thus, the concept of topics is related to matters discussed in the discourse [8]. Disclosure of this topic isuseful to see what ecomes the focus of each news headline and article which have been stipulated as the object of study. In this study, the Content Analysis is made as the additional science which is used to reveal the content of sites, so as to identify the identity and ideology of the site administrators or content filler. The Content Analysis itself is a scientific methodology which is usedin the field of humanities to review the authorship, authenticity, or meaning. Palmquist [9] asserted that the Content Analysis is a research device which is focused on actual content and internal features of a media which takes a look at the use of words, concepts, themes, phrases, characters or sentences in a text or a group of texts. 
In this study, the range of written language is used as a data with the consideration that the range of written language is more stable and well-planned. In other words, content that will be analyzed is only limited to the written content on the sites and does not involve visual and auditory content. The main data sources in this study are the editorial and the content of voa -islam.com and panjimas.com. This study is a qualitative case study [10]. In other words, this study will observe, describe, analyze, and explain the contents of the sites. In general, the method used in this research is to examine the electronic data. The steps in determining the identity and ideology of the sites can chronologically be broken down as follows: (1) observe the site administrator's identity through the information can be found on the column "tentang" (about) and other supporting information; (2) observe and formulate the headlines of the sites containing hateful speech to a group, concept, and other religions; (3) observe and formulate the news content of the site containing hateful speech towards a group, concept and other religions. Data collection is done by taking the data from the source aforementioned by using "tapping and recording" technique [11]. The Information obtained will then be collected to ease the observation of the ideology respective Islamic group based on the content on the site. The data collected serves as a sample to find a conclusion which in turn is expected to also reach the data which have not been found at the time of the study.

\section{RESULT AND DISCUSSION}

The objects of this study are voa-islam.com panjimas.com, who were indicated spread ideology against the state ideology. It is based on a search by entering keyword Pancasila after the code search site: www.panjimas.com acquired 299 entries which were indexed to discuss issues on Pancasila in various kinds of data (articles, news, reviews, and photos). Meanwhile, from Voa -Islam the data acquired 10,600 posts that talked about Pancasila. Meanwhile, by entering the keyword Islamic Law, data showed there were 845 articles and news on the site panjimas.com discussing the issue with various forms. Based on the data obtained from the site Voa-Islam.com, there were 13,700 articles or news that contains the keywords of Islamic law.

Voa-Islam was launched in Bekasi at 1 June 2009. In 2013, Voa-Islam claimed that it was the biggest four as a most popular of Islamic online media in Indonesia. Voa -Islam is lead by Sabrun Jamil. Based on Alexa, until September 2017 this site ranked in 75.913 in global rank and 1,274 in national rank. This site was also one of the sites has reportedly blocked by The Indonesian Communications and Information Ministry because this site that violates the Press Law and other regulations.

Meanwhile, Panjimas was formerly one of the magazines of Muhammadiyah. In Soekarno Era, this magazine has been closed. In Reform Era, Panjimas was published in online version metamorphosed into Panjimas.com. This site lead by Widi Y and Ranu Muda. Ranu was arrested by Indonesian Police on his sweeping and his report about Social Kitchen, a restaurant which sells liquors in Solo, Central Java. Panjimas.com was launched at 27 Juni 2014. Based on Alexa, until September 2017 this site ranked in 188.818 in global rank and 3.657 in national rank.

Based on this raw data, it can be temporarily concluded that Voa-Islam gave more attention to issues regarding Pancasila as the state ideology and Islamic law that has to be implemented. Keeping in mind a large amount of data which were dispersed related to the issues of Pancasila and Islamic law, then this research will only focus on articles and news which were published in the period of between 2015-2016. The articles and news which are analyzed are first categorized based on the subtopics and sub-issues which becomes the main focus related to the issues of Pancasila and Islamic Law on both sites. The analysis will only be conducted on articles and news which includes the word Pancasila and Islamic Law as the title. The articles and news must also be related to Indonesia.

In the period of 2015-2016, the news and articles published on Panjimas related to the keyword Pancasila have not been as harsh anymore. The inclusion of the word antiPancasila as the ideology of the Unitary State of the Republic of Indonesia is only very clear from the publicat ion of two articles continuous with the title "Lahirnya Ilyasiq Modern Khams Qanun" (The Birth of the Modern Pancasila) part 1 and $2(1 / 6 / 2014)$.

The anonymous article criticizes and corrects Pancasila. In the first part, the writer concluded that the teaching contained in Pancasila was a realization of the teachings of Zionism which was spread by Jewish Freemasonry network. Following is the excerpt from the article:

"Gerakan Zionisme dan Freemasonry di seluruh dunia sesungguhnya memiliki asas yang sama. Asas dari dua gerakan ini disebut "Khams Qanun", lima sila, atau Panca Sila. Asas ini tentu saja diajarkan kepada seluruh anggotanya yang kelak menjadi pemimpin di negaranya" [14].

(The Zionism and Freemasonry movements all around the world actually have the same principle. The principle from the two movements is called "Khams Qanun", five principles or Panca Sila. This principle is certainly taught to all its members who later then will become leaders in their respective country).

In the second part of the article, Pancasila was even clearly stated as physically and legally as berhala (worship idol).

"Burung Garuda sejatinya tidak pernah ada di dunia ini, bahkan lambang burung garuda ini di duga kuat merupakan lambang paganis yang terinspirasi dari lambang dewa Horus sebagai kepercayaan rakyat mesir yang dipercaya hidup pada 3000 SM. Zionis Yahudi memang kerap menandai suatu Negara yang berada di bawah pengaruhnya dengan lambang burung, dan itu bisa kita lihat seperti Negara Amerika Serikat. Selanjutnya bukan hanya sebagai pagan (berhala) thaghut secara fisik 


\section{Garuda Pancasila juga menjadi thaghut dalam hal hukum" [15].}

Garuda bird actually never existed in this world, even the emblem of this Garuda bird is strongly suspected to be the symbol of pagans inspired by the symbol of the god Horus which Egyptian believed to live in 3000 BC. Zionist Jews often mark a State under its influence with the symbol of a bird, and it can be seen in the United States. Furthermore, not only as a pagan (idol) thaghut, physically Garuda Pancasila also become thaghut in legal matters).

Different from Panjimas which in 2015-2016 only published several articles criticizing and degrading the state ideology, voa-islam.com published more articles and news which tend to be against Pancasila. The result of the investigation from January 2015 to October 2016, found that there are 22 articles and news published which put the word Pancasila in the title.

Among the 22 news, not all of them really published hatred towards Pancasila. Some news discussed issues which can be classified as opposing Pancasila, such as an article entitled "Bela Pancasila tapi Sembah Berhala" (Defend Pancasila but Worship Idol). These were natural since the dislike and hatred towards Pancasila have already become the reason to mock Pancasila.

The insertion of thoughts to doubt and weaken Pancasila was clearly seen from an article entitled "Pantaskah Pancasila Menyandang Sebutan Ideologi?" (Does Pancasila deserve to be an Ideologi?) which was published in 2 series. In this article, Abu Hamzah Rizal besides asking conclusion that Pancasila is not worth to be an ideology also stated that Pancasila come from the teaching of the Jews.

\begin{abstract}
"Kalaupun Pancasila dimaknai sebagai nilai yang mengandung penghargaan terhadap keberagaman, itu bukanlah genuine milik Pancasila. Keberagaman yang sering dimaknai dalam Pancasila adalah keberagaman dari versi ideologi pluralisme. Nilai-nilai pluralisme tersebut terdapat juga dalam Five Principles yang merupakan dasar negara Pakistan. Juga dalam San MIn Chu I, ideologinya Sun Yat Sen. Bahkan lebih jauh lagi nilai-nilai pluralisme terdapat juga dalam Five Principles of Zionism, dimana dengan jelas sekali bahwa ke lima sila dalam Pancasila sangat mirip dengan ke-5 prinsip zionisme tersebut" [16].
\end{abstract}

(Even if Pancasila is meant as a value containing appreciation towards diversity, that is not genuinely owned by Pancasila. The diversity which has been meant in Pancasila is the diversity from the ideological version of pluralism. The values of pluralism are also present in the Five Principles which is the national foundation of Pakistan, also in San Min Chu I, the ideology of Sun Yat Sen. Even further, the values of pluralism are also present in the Five Principles of Zionism, where it is very clear that the five principles in Pancasila are very similar to the 5 Zionism principles).

In the footnote, the writer explains:
"Five Principles of Zionism adalah:1. Monotheisme, 2. Nasionalisme, 3. Humanisme, 4. Demokrasi, 5. Sosialisme. Azas freemasonry dan zionisme pada dasarnya sama, hanya berbeda pada urutannya saja. Keduanya diilhami oleh ajaran Talmud, kitab suci agama Yahudi."

The Five Principles of Zionism are: 1. Monotheism, 2. Nationalism, 3. Humanism, 4. Democracy, 5. Socialism. The principle of Freemasonry and Zionism are basically the same, but only different in terms of the order of the principles. Both are inspired by the teachings of Talmud, the bible of Judaism.

In a glance, there are not any articles which show too much hatred to the ideology of the state in the time frame of 2015-2016. But when taking back to the vista of years up to 2011, the site Voa-Islam actually has published a lot of articles of hatred towards Pancasila. For example the article entitled: "Abu Jibril: Yang Ikut Pancasila Akan Binasa” (Abu Jibril: Pancasila Followers will be Banished)" (08/6/2011), "Ustadz Ba'asyir: Pancasila adalah Ideologi Syirik, Haram Diamalkan" (Ustadz Ba'asyir: Pancasila is the ideology of Syirik, it is Haram to be Carried Out) (14/8/2013), and the "Majelis Mujahidin Akan Gugat Pancasila Sebagai Dasar Negara ke MK" (Majelis Mujahidin will Sue Pancasila as the Foundation of the State to the MK" (7/5/2013). From the analysis of data obtained, it can be concluded that in terms of discussing the issues regarding Pancasila not to be worthy to become the ideology of the state, the site Voa Islam has certainly intensely published articles that focus on Pancasila.

Based on an analysis of editorial and news content or article, it is concluded that the websites, in general, are dominated by sites that have the identity or affiliated to the Salafi groups. In the Salafi ideology, the state ideology must be in syariah or khilafah [12]. Ideologization of tenet is done by taking a stance in responding to current issues surrounding the Islamic world both nationally and internationally. News and articles which are written are directed to support the ideology that they hold and are developed by the administrators. Ideological affiliates and alliance with other parties both inside and outside the country participated in forming the discourse patterns that are built.

In the context of Indonesia, these radical groups have started to grow and develop after the fall of the New Order. The euphoria of the Reform Era makes the state loose its control in handling the ideologies that is developing in the community, including the ideologies which actually threaten the state ideology. According to Turmudi and Sihbudi, et al. [13], in the Indonesian political constellation, the problem of Islamic radicalism continues to expand because its supporters are also increasing. However, radical movements sometimes have different purposes and don't have the same pattern. Some only fight for the implementation of Islamic law without having to establish an 'Islamic state', but some are fighting for the establishment of 'Islamic state of Indonesia', in addition to fighting for the establishment of 'Islamic caliphate'. 


\section{CONCLUSION}

Websites that have the same bearing, in general act in the same way in responding to issues which are developing especially related to attitudes towards the government, democracy, the implementation of the shariah, Khilafah, also related to the attitude towards the opinions and other groups which has different bearing that are commonly called by online media of radical Islam as misguided. From the title and the narration of news and articles written, the ideology of a site can be known. The ideological pattern can also be further seen related to the consistenc y of both websites in developing a particular discourse that has been set as the ideology of the administrators.

\section{REFERENCES}

[1] I. N. Bhakti, "The Transition to Democracy In Indonesia: ome Outstanding Problems,"” in Jim Rolfe (Ed). The Asia-Pacific: A Region in Transition, Honolulu: APCSS, 2004, p. 195.

[2] Moch. Syarif Hidayatullah, "The Sectarianism Ideology of the Islamic Online Media in Indonesia," Insaniyat J. Islam Humanit., vol. 1, no. 2, pp. 141-151, 2017.

[3] A. Azra, Indoneia, Islam and Democracy: Dynamics in a Global Context. Jakarta: The Asia Foundation, 2006.

[4] G. Fealy and S. White, Expressing Islam: Religious Life and Politics in Indonesia. Singapore: ISEAS, 2008.

[5] L. Assyaukanie, Islam and the Secular State in Indonesia. Singapura: ISEAS, 2009.

[6] Carool Kersten, Islam in Indonesia: The Contest for Society, Ideas and Values. London: Hurst \& Company, 2015.

[7] J. Gundel, N. Hedberg, and R. Zacharski, "Topic-Comment Structure, Syntactic Structure and Prosodic Tune," presented at the Workshop pada Prosody and Grammar in Interaction, Helsinki, Finland, 1997, p. 1

[8] Renkema, Discourse Studies. Amsterdam: John Benjamin, 1993, p. 64.

[9] M. Palmquist, "Content Analysis," 1990. [Online]. Available: http://writing.colostate.edu/guides/pdfs/guide61.pdf. [Accessed: 16Feb-2017].

[10] S. B. Merriam, "Case Study Research in Education: A Qualitative Approach," in Nunan, David. 1992. Research Methods in Language Learning, Cambridge: Cambridge University Press, 1998, p. 16.

[11] M. S. Mahsun, Penelitian Bahasa: Berbagai Tahapan Strategi, Metode, dan Teknik-tekniknya. Mataram: Universitas Mataram, 2000 pp. 66-67.

[12] C. Bunzel, From Paper State to Caliphate: The Ideology of the Islamic State. Brookings: CMEP, 2015.

[13] E. Turmudi and Riza Sihbudi (Ed.), Islam dan Radikalisme di Indonesia. Jakarta: LIPI Press, 2005, p. 5.

[14] http://www.panjimas.com/kajian/2014/06/01/lahirnya-ilyasiq-modernkams-qanun-pancasila-bag-1/

[15] http://www.panjaimas.com/uncategorized/2014/06/01/lahirnya-ilyasiqmodern-khams-qanun-pancasila-bag-2/

[16]http://www.voa-islam.com/read/citizensjurnalism/2015/12/08/41020/pantaskah-pancasila-menyandangsebutan-ideologi(bagian-1/\#sthash.SVQz3At4.dpbs. 